\title{
STUDI KUALITAS ORGANOLEPTIK KULIT BABI GULING DARI BAHAN BAKU BABI BALI DAN BABI LANDRACE
}

\author{
SRIYANI, N. L. P. DAN A. A. OKA \\ Program Studi Peternakan, Fakultas Peternakan, Universitas Udayana, Denpasar \\ e-mail: sriyaninlp@yahoo.co.id
}

\begin{abstract}
ABSTRAK
Penelitian bertujuan untuk mengetahui perbandingan kualitas organoleptik kulit babi guling yang berasal dari babi bali dan babi landrace. Kulit babi guling ini adalah salah satu bagian dari babi guling yang paling digemari konsumen, bentuk dan teksturnya hampir menyerupai kerupuk. Babi yang digunakan pada penelitian ini adalah babi bali yang yang didatangkan dari Desa Gerokgak, Kabupaten Buleleng dipelihara secara ekstensif dengan diberikan pakan tradisional seadanya dan babi landrace dipelihara secara intensif yang diberikan pakan komersial. Berat babi yang digunakan relatif sama yaitu $\pm 20 \mathrm{~kg}$ dan dilanjutkan dengan proses penggulingan. Selanjutnyau uji organoleptik kulit babi guling dilakukan dengan menggunakan uji hedonik kepada 20 panelis semi terlatih. Uji hedonik yang dilakukan meliputi warna, aroma, tekstur, citarasa, ketebalan kulit, kerenyahan (crispy) dan penerimaan keseluruhan. Data yang diperoleh dianalisis menggunakan analisis non-parametrik dengan uji-t menurut Mann-Whitney dibantu dengan program SPSS 16. Dari hasil penelitian didapatkan tingkat kesukaan panelis terhadap variabel warna, aroma, tekstur, cita rasa, ketebalan kulit dan kerenyahan (crispy) dari kulit babi guling yang berasal dari babi bali nyata lebih tinggi daripada babi landrace $(\mathrm{P}<0,05)$. Dapat disimpulkan bahwa panelis lebih menyukai kulit babi guling yang berasal dari babi bali daripada babi landrace.
\end{abstract}

Kata kunci: kulit, organoleptik, babi

\section{ORGANOLEPTIC QUALITY STUDY ON PIG CRACKERS OF BALI PIG AND LANDRACE PIG}

\begin{abstract}
The study aims to findout of organoleptic comparison qualities skin of suckling pig from bali pig and landrace pig. This skin of suckling pig the most popular of consumers whose form and texture is almost like a cracker. Bali pig use in the study was came from Gerokgak Village Buleleng District, the bali pig was fed traditional and landrace pig on another hand came from Dalung and was fed with commercial feeding. The weight of both pigs were similar and continued both grilled process. The organoleptic test using a hedonic test to 20 semi-trained panelists. Hedonic test performed include color, aroma, texture, flavor, skin thickness, crispness and overall acceptability. The data obtained were analyzed using Non-parametric analysis with t-test according to Mann-Whitney with SPSS 16.0 program. Result of the research, it was found that the panelist's favorite level of variables color, aroma,texture, taste, skin thickness and crispy from bali pig were significantly higher than landrace pig $(\mathrm{P}<0.05)$. Overall panelist acceptance of pork crackers products from bali pig is significantly higher than landcrace pig.
\end{abstract}

Keywords: crackers, organoleptic, pig

\section{PENDAHULUAN}

Daging yang umum dikonsumsi dan dipasarkan di Indonesia adalah daging sapi, domba, kambing, babi, ayam, itik, ikan dan lainnya. Khusus di pulau Bali sebagian besar masyarakatnya mengkonsumsi daging babi dibandingkan daging ternak lainya. Daging babi yang beredar dipasaran adalah daging babi bali dan babi landrace. Kedua ternak babi tersebut berasal dari bangsa yang berbeda dan pada umumnya melalui manajemen pemeliharaan yang berbeda. Babi bali merupakan babi tipe lemak dan dipelihara secara tradisional dengan pakan bernutrisi rendah seperti dedaunan dan limbah dapur (Budaarsa et al., 2016), 
sehingga daging babi bali memiliki daging yang cukup berlemak. Babi landrace merupakan tipe pedaging dan lemak (dwi guna) dengan pakan bernutrisi tinggi seperti ransum dan konsentrat (Sihombing, 2006), oleh karena itu daging babi landrace memiliki kandungan lemak yang rendah dan kandungan protein yang cukup tinggi.

Ternak babi selama ini sering digunakan sebagai produk babi guling. Babi guling di Bali merupakan kuliner tradisional yang sangat digemari masyarakat bali. Pemanfaatan babi guling selain sebagai konsumsi yang sering dijual dalam bentuk nasi babi guling juga banyak digunakan sebagai sarana upacara. Dalam pembuatan babi guling biasanya masyarakat lebih menyukai babi bali sebagai bahan baku untuk babi guling. Di pasaran daging guling babi bali lebih disukai dari pada babi ras karena citarasa daging guling babi bali lebih gurih daripada daging babi ras (Budaarsa, 2012). Namun beberapa industri pembuatan babi guling menyatakan bahwa pasokan babi bali sebagai bahan baku babi guling akhir-akhir ini mulai terbatas sehingga alternatif bahan baku dari babi ras atau babi landrace juga sering digunakan untuk babi guling.

Salah satu indikator kualitas babi guling yang baik di masyarakat adalah berdasarkan dari kualitas kulit babi gulingnya. Indikator yang digunakan oleh konsumen adalah warna kulit, kerenyahan,cita rasa, dan ketebalan kulit. Konsumen menilai bahwa kulit babi guling yang berasal dari bahan baku babi bali memiliki kualitas yang lebih baik daripada babi ras dilihat dari warna, kerenyahan, cita rasa maupun ketebalannya. Namun sampai sekarang penelitian secara ilmiah belum dilakukan untuk melihat perbandingan kualitas organoleptik kulit babi guling pada babi bali dengan babi landrace.

\section{MATERI DAN METODE}

\section{Lokasi dan Waktu Penelitian}

Penelitian dilaksanakan di rumah potong hewan (RPH) tradisional dan Laboratorium Teknologi Hasil Ternak dan Mikrobiologi Fakultas Peternakan Univeritas Udayana. Pembuatan babi guling dilaksanakan di RPH tradisional milik Bapak I Wayan Patra yang berlokasi di di Banjar Peginding, Desa Dalung, Kecamatan Kuta Utara. Uji organoleptik dilaksanakan di Lab. THT dan Mikrobiologi.

\section{Materi dan Metode}

Materi yang digunakan dalam penelitian ini adalah babi bali dan babi landrace yang digunakan sebagai bahan baku babi guling. Berat babi yang digunakan relatif sama yaitu $\pm 20 \mathrm{~kg}$. Babi ini dipotong di rumah potong hewan tradisional. Selanjutnya kedua jenis babi ini dibuat produk babi guling. Setelah babi guling selesai dibuat maka dilanjutkan uji organoleptik terhadap kulit babi guling dengan menggunakan panelis semi terlatih menggunakan mahasiswa Fakultas Peternakan semester VI.

\section{Variabel yang diamati Warna kulit babi guling}

Warna merupakan salah satu sifat dari organoleptik yang utama, penelitian secara subjektif dengan penglihatan sangat menentukan dalam pengujian organoleptik warna. Penilaian terhadap warna dapat dilakukan dengan menggunakan indra penglihatan yaitu mata, warna dibedakan berdasarkan tingkat kesukaan di masing-masing sampel.

\section{Aroma kulit babi guling}

Aroma merupakan suatu sifat mutu produk yang penting untuk diperhatikan dalam penilaian organoleptik, serta merupakan faktor yang sangat berpengaruh pada daya terima konsumen. Penilaian terhadap aroma dapat dilakukan dengan menggunakan indera penciuman yaitu hidung.

\section{Keempukan/kerenyahan kulit babi guling}

Keempukan/kerenyahan merupakan sifat organoleptik kulit babi guling yang bisa di uji dengan menggunakan gigi atau mulut. Panelis akan mengunyah sampel kulit babi guling selanjutnya akan memberikan penilaian tingkat keempukan/kerenyahannya.

\section{Uji Citarasa}

Rasa merupakan kualitas organoleptik yang berkaitan dengan indera perasa yaitu lidah. Citarasa produk dapat dinilai dengan cara mengkonsumsi produk tersebut, selanjutnya memberikan penilaian terhadap tingkat cita rasa yang dirasakan oleh panelis.

\section{Penerimaan keseluruhan}

Daya terima penerimaan keseluruhan merupakan bagian dari parameter organoleptik produk untuk tingkat penerimaan konsumen terhadap semua parameter organoleptik. Penerimaan keseluruhan berguna juga dalam memberikan kesimpulan manakah dari uji organoleptik yang paling baik dan disukai panelis.

\section{Analisis Statistik}

Data organoleptik yang diperoleh dari penelitian ini dianalisis menggunakan analisis non-parametrik dengan uji-t menurut Mann-Whitney (Saleh, 1996) dengan bantuan program SPSS 16 . 


\section{HASIL DAN PEMBAHASAN}

Berdasarkan analisis perbandingan dengan menggunakan uji Non-Parametrik Mann-Whitney antara kulit babi guling babi bali (BB) dengan kulit babi guling babi landrace (BL) menunjukkan bahwa warna kulit babi guling dari babi bali (BB) memperoleh angka 4,45 sedangkan warna kulit babi guling dari babi landrace (BL) memperoleh angka 3,45 (Tabel 1). Terlihat bahwa tingkat kesukaan panelis terhadap warna kulit babi guling pada perlakuan babi bali 22,47\% lebih besar dibandingkan pada babi landrace. Secara statistik tingkat kesukaan panelis terhadap warna kulit babi guling berbeda nyata atau signifikan $(\mathrm{P}<0,05)$. Warna dari suatu produk pangan merupakan salah satu indikator yang penting. Penilaian secara subyektif dengan menggunkaan panca indra sangat menentukan dalam pengujian organoleptik warna. Hasil penelitian menunjukkan bahwa tingkat kesukaan panelis terhadap warna kulit babi guling babi bali lebih tinggi dibandingkan dengan babi landrace. Hasil ini menunjukkan bahwa warna kulit babi guling dari babi bali lebih disukai daripada babi landrace. Hal ini disebabkan karena setelah melalui proses mengguling kulit babi guling berwarna lebih coklat dan tampak terlihat lebih berkilau daripada kulit babi landrace. Lemak subkutan yang lebih banyak dan lebih tebal yang terdapat pada babi guling babi bali menyebabkan produk babi guling dari babi bali lebih banyak dilumuri lemak sehingga lebih kelihatan lebih berkilau daripada babi landrace.

Tabel 1. Hasil uji organoleptik kulit babi guling dari babi bali dan babi landrace

\begin{tabular}{lccc}
\hline \multirow{2}{*}{ Variabel } & \multicolumn{2}{c}{ Perlakuan $^{1)}$} & \multirow{2}{*}{ SEM ${ }^{2)}$} \\
\cline { 2 - 3 } & \multicolumn{1}{c}{$\mathrm{BB}$} & $\mathrm{BL}$ & \\
\hline Warna & $4,45^{\mathrm{b} 3)}$ & $3,45^{\mathrm{a}}$ & 0,19 \\
Aroma & $4,55^{\mathrm{b}}$ & $3,40^{\mathrm{a}}$ & 0,19 \\
Tekstur & $4,35^{\mathrm{b}}$ & $3,30^{\mathrm{a}}$ & 0,21 \\
Citarasa & $4,35^{\mathrm{b}}$ & $3,65^{\mathrm{a}}$ & 0,28 \\
Ketebalan & $4,85^{\mathrm{b}}$ & $2,6^{\mathrm{a}}$ & 0,16 \\
Kerenyahan/crispy & $4,75^{\mathrm{b}}$ & $3,0^{\mathrm{a}}$ & 0,24 \\
Penerimaan keseluruhan & $4,60^{\mathrm{b}}$ & $3,50^{\mathrm{a}}$ & 0,26 \\
\hline
\end{tabular}

Keterangan:

1) $\mathrm{BB}=$ Babi bali; $\mathrm{BL}=$ Babi landrace

2) $\mathrm{SEM}=$ "Standar Error of the Threatment Means

3) Nilai dengan huruf yang berbeda menunjukan perbedaan nyata atau signifikan $(P<0,05)$

Warna coklat pada kulit babi guling bisa terjadi karena adanya reaksi millard yang terjadi yaitu gugus karbonil dari gula reduksi bereaksi dengan gugus amino dari protein pada kulit babi guling dan asamasam amino secara non enzimatik, dan hasil reaksinya menimbulkan warna coklat. Dalam pembuatan babi guling ini sebelum dilaksanakan penggulingan pada api maka karkas babi guling dilumuri terlebih dahulu dengan air kelapa. Salah satu kandungan air kelapa yang dominan adalah glukosa. Jadi glukosa yang ada pada air kelapa menimbulkan reaksi millard yang memberikan dampak warna coklat pada permukaan babi guling. Reaksi Millard terjadi karena adanya gula reduksi yang bereaksi dengan gugus amina primer (Sirkorski, 2007)

Hasil uji organoleptik pada penelitian ini menunjukkan bahwa tingkat kesukaan panelis terhadap aroma kulit babi bali lebih tinggi dan secara statistik berbeda nyata $(\mathrm{P}<0,05)$ dibandingkan dengan kulit babi guling dari babi landrace. Hal ini menunjukkan bahwa aroma kulit babi guling dari babi bali lebih spesifik dibandingkan dengan babi landrace. Sesuai dengan pendapat Budaarsa (2012), bahwa aroma spesifik daging babi yang dimasak berasal dari lemak daging yang dipanaskan, oleh karena itu semakin tinggi kandungan lemak daging maka akan semakin spesifik aroma daging tersebut.

Tipe babi bali adalah tipe lemak sementara babi landrace adalah tipe daging lemak (bacon type). Pada babi tipe lemak maka kandungan atau jumlah lemak pada depot-depot lemak karkas lebih tinggi daripada tipe bacon atau tipe daging. Depot-depot lemak karkas ini antara lain lemak internal, lemak inter muskuler, lemak subkutan dan lemak intra muskuler. Jumlah lemak pada babi bali terutama lemak subkutan yang berada dibawah kulit diduga memberikan kontribusi aroma yang lebih baik pada babi bali daripada babi landrace. Hasil kandungan lemak pada dagingya pun menunjukan bahwa kadar lemak pada daging babi bali $11,13 \%$ lebih tinggi dibandingkan kadar lemak pada babi landrace 7,63\% (Suandita, 2016). Alasan lain yang diduga menyebabkan aroma daging babi bali yang telah dimasak lebih spesifik dibandingkan dengan babi landrace adalah, persentase kandungan asam lemak tak jenuh daging babi bali lebih tinggi dibandingkan daging segar babi landrace (Sriyani et al., 2017).

Menurut Soeparno(2009), lemak daging dipengaruhi oleh umur ternak, jenis pakan, lama dan kondisi penyimpanan setelah dipotong, faktor-faktor tersebut akan mempengaruhi kualitas lemak yang terdapat pada daging ternak. Secara genetik babi bali termasuk tipe lemak, berbeda dengan babi ras yang sebagian besar tipe daging, jadi babi bali lebih cepat menimbun lemak dalam tubuhnya, sehingga lemak punggungnya lebih tebal dibandingkan babi ras. Budaarsa (2012) menyatakan, bahwa ketebalan lemak pada punggung merupakan hal yang baik pada pembuatan babi guling, karena lemak di bawah kulit ketika panas akan cair meresap ke dalam daging dan keluar melumuri kulit sehingga memberi aroma spesifik.

Tekstur kulit babi guling pada uji organoleptik menunjukkan bahwa tingkat kesukaan panelis terhadap 
tekstur daging babi bali lebih tinggi dan berbeda nyata $(\mathrm{P}<0,05)$ dibandingkan dengan daging babi landrace. Tekstur kulit babi giling pada babi bali terlihat lebih merata, kuat dan halus. Jika dilihat dari tipe babi bali dan babi landrace sangat berbeda jauh, babi bali tipe lemak dan dan babi landrace tipe bacon (daging lemak). Ini memberikan dampak pada tebal lemak subkutan atau lemak dibawah kulit pada babi guling dari babi bali jauh lebih tebal daripada babi landrace. Pada penelitian yang dilaksanakan oleh Sriyani (2016) (unpublish) tebal lemak punggung pada babi bali dengan rata - rata berat potong $20 \mathrm{~kg}$ adalah $11,11 \mathrm{~mm}$ sementara tebal lemak punggung babi landrace 8,1 $\mathrm{mm}$. Hal ini diduga memberikan tekstur yang lebih baik pada kulit babi guling dari babi bali karena pada saat proses penggulingan ada lebih banyak lemak yang menetes keluar dan melumuri kulit pada babi guling. Hal ini menyebabkan kulit babi guling pada babi bali lebih berminyak dan membuat tekstur lebih halus.

Citarasa merupakan kualitas organoleptik daging yang dinilai melalui indra pengecap pada lidah dan bibir. Hasil penelitian menunjukkan bahwa tingkat kesukaan panelis terhadap citarasa kulit babi guling dari babi bali nyata $(\mathrm{P}<0,05)$ lebih tinggi dibandingkan dengan daging babi landrace. Hal tersebut menunjukan bahwa setelah melalui proses pemasakan dengan cara diguling citarasa daging babi bali lebih gurih dari pada daging babi landrace. Pada umumnya rasa gurih pada olahan daging berasal dari proses pelelehan lemak daging yang terjadi pada saat proses penggulingan. Tebal lemak punggung babi bali lebih tinggi daripada babi bali dan ini menyebabkan pada saat kulit babi guling dikonsumsi maka lemak dibawah kulit pun akan ikut terkonsumsi. Hal ini diduga memberikan sensansi rasa yang lebih gurih pada kulit babi guling pada babi bali. Rasa gurih pada makanan pada umumnya di sebabkan oleh komponen lemak. Lemak juga memberikan cita rasa dan aroma spesifik pada makanan yang tidak dapat di gantikan oleh komponen makanan lainnya. Sesuai dengan hasil penelitian Suandana et al. (2016), daging babi bali memiliki citarasa yang lebih gurih dibandingkan dengan babi ras. Salah satu faktornya adalah karena babi bali merupakan tipe lemak sedangkan babi landrace merupakan babi tipe dwi guna yaitu tipe daging dan sedikit lemak. Sehingga lemak yang terkandung dalam daging babi bali lebih tinggi dibandingkan dengan daging babi landrace.

Faktor makanan juga berpengaruh pada kandungan lemak pada depot depot lemak karkas, dimana pakan yang dikonsumsi babi bali adalah pakan yang mengandung karbohidrat cukup tinggi misalnya: umbiumbian. Karbohidrat yang didapat dari pakan tersebut akan disimpan dalam bentuk lemak. Kandungan lemak daging mempengaruhi citarasa daging setelah melalui proses pemasakan, sehingga daging babi bali yang mengandung lemak yang lebih banyak menghasilkan citarasa yang lebih gurih dibandingkan dengan babi landrace yang memiliki kandungan lemak lebih rendah.

Berdasarkan analisis perbandingan dengan menggunakan uji Non-Parametrik Mann-Whitney antara kulit babi guling dari babi bali dengan babi landrace menunjukkan bahwa ketebalan kulit babi guling dari babi bali nyata lebih tinggi daripada kulit babi guling babi landrace. Hal ini disebabkan karena perbedaaan genetik pada kedua bangsa ini, yang menyebabkan perbedaan bentuk tubuh, warna maupun ketebalan kulit. Babi bali ciri-cirinya warna bulu hitam agak kasar ada pula yang belang putih bagian perut, punggungnya melengkung dan telinga tegak. Babi bali memiliki perlemakan daging yang lebih tinggi dibandingkan dengan babi landrce, karena secara genetik bangsa babi bali ini termasuk dalam bangsa babi tipe lemak (lard type). Babi landrace persilangan mempunyai ciri-ciri berwarna putih, daun telinga jatuh, tubuh panjang, dan kaki pendek. Babi landrace memiliki perdagingan yang lebih banyak serta perlemakan yang lebih sedikit daripada ternak babi lainnya (Anom,1985) dalam Sudana (1997).

Daya terima merupakan bagian dari parameter organoleptik untuk tingkat penerimaan konsumen terhadap semua sifat organoleptik suatu produk. Penilaian akhir atau penerimaan produk didasarkan atas tingkat daya terima konsumen secara keseluruhan dan yang mendasari panelis memutuskan produk mana yang paling diterima atau disukai panelis. Kepuasan yang berasal dari konsumen tergantung pada respon fisiologis dan organoleptik diantara masing-masing individu konsumen.

Hasil analisis statistik dari uji organoleptik pada penelitian ini menunjukan bahwa skor daya terima kulit babi guling dari babi bali dengan babi landrace memiliki perbedaan yang nyata $(\mathrm{P}<0,05)$. Berdasarkan hasil analisis, kulit babi guling babi bali memiliki skor penerimaan yang lebih tinggi dibandingkan dengan babi landrace artinya bahwa panelis lebih menyukai kulit babi guling babi bali dibandingkan dengan babi landrace. Hal tersebut kemungkinan disebabkan karena pada penilaian terhadap aroma, tekstur dan citarasa, ketebalan, kerenyahan kulit babi guling dari babi bali lebih disukai dibandingkan babi landrace. Aroma kulit babi guling dari babi bali dinilai lebih spesifik dan citarasa dinilai lebih gurih dibandingkan babi landrace.

Tekstur merupakan sifat organoleptik yang berkaitan dengan tingkat kehalusan. Sedangkan aroma dan citarasa merupakan sebuah sifat organoleptik yang memberikan nilai yang tinggi terhadap tingkat penerimaan konsumen pada suatu bahan pangan, oleh sebab itu secara keseluruhan konsumen lebih menyukai 
kulit babi guling dari babi bali karena memiliki aroma, tekstur dan citarasa yang lebih baik.

\section{SIMPULAN}

Dapat disimpulkan bahwa berdasarkan penerimaan secara keseluruhan panelis lebih menyukai kulit babi guling yang berasal dari babi bali dibandingkan dengan babi landrace. Hal ini terlihat dari semua variabel organoleptik dimana panelis lebih menerima kulit babi guling dari babi bali daripada babi landrace.

\section{UCAPAN TERIMAKASIH}

Ucapan terimakasih disampaikan kepada Direktorat Jendral Pendidikan Tinggi melalui Hibah Unggulan Udayana. Terimakasih juga penulis sampaikan kepada staf Laboratorium Teknologi Hasil Ternak dan Mikrobiologi Fakultas Peternakan Universitas Udayana.

\section{DAFTAR PUSTAKA}

Budaarsa, K. 2012. Artikel babi guling bali dari beternak, kuliner, hingga sesaji. http://www.fapet.unud.ac.id/ wp-content/uploads/babi-guling-Bud.pdf

Budaarsa K., A. W Puger, I M. Suasta. 2016. Eksplorasi Komposisi Pakan Tradisional Babi Bali. Majalah Ilmiah Peternakan Peternakan Vol. 19 No 12016.
Saleh, S.1996. Statistik Non Parametrik. Penerbit BPFE Yogyakarta.

Sudana, I. B. 1997. Studi Pengaruh Komposisi dan Frekwensi Pemberian Ransum terhadap Kualitas Babi Guling. Disertasi. Program Pascasarjana Institut Pertanian Bogor.

Sihombing, D. T. H. 2006. Ilmu Ternak Babi. Gadjah Mada University Press. Yogyakarta.

Sirkorski, Z.E.J., Pokorny dan S. Damodaran, 2007. Fenema's Food Chemistry $4^{\text {th }}$ Edition: Physical and Chemical Interactin of Component in Food System. CRC Press. Boca Raton. London. New York.

Soeparno, 2009. Ilmu dan Teknologi Daging. Gajah Mada University Press. Yogyakarta.

Suandana, I W. E. E., N. L. P. Sriyani dan M. Hartawan 2016. Studi Perbandingan Kualitas Organoleptik Daging Babi Bali dengan Daging Babi Landrace. E-Journal Peternakan Tropika Vol. 4 No. 2 Th. 2016: 405- 418

Suandita, I W. E., N. L. P. Sriyani dan I G. Suranjaya 2016. Studi Perbandingan Kandungan Nutrien Daging. EJournal Peternakan Tropika Vol. 4 No. 3 Th. 2016: $713-723$

Sriyani N. L. P., M. A. Rasna, I N. T. Ariana, dan A. W. Puger. 2017. Profil Asam Lemak Daging Babi Bali Asli dan Babi Landrace. Majalah Ilmiah Peternakan Volume 20 No. 1, Hal 12-15. 